Gordon, I. R. S., and Tucker, J. F. (1945). Fournal of Neurology, Neurosurgery, and Psychiatry, $8,40$.

McAlpine, D., Kuroiwa, Y., Toyokura, Y., and Araki, S. (1959). fournal of Neurology, Neurosurgery, and Psychiarry, 22, 120

McAlpine, D., Lamsden, C. E., and Acheson, E. D. (1965). Multiple Sclerosis. Edinburgh, Livingstone.

Miller, H., Cendrowski, W., and Schapira, K. (1967). British Medical

7ournal, 2, 210.
Ross, C. A. C., Lenman, J. A. R., and Rutter, C. (1965). British Medical foumal, 1,226 .
Sibley, W. A., and Foley, J. M. (1965). Annals of the New York Academy of Science, 122, 457 .

Smith, H. V., Espir, M. L. E., Whitty, C. W. M., and Russell, w. R. (1957). Fournal of Neurology, Neurosurgery, and Psychiatry, 20, 1 Webb, H. E. (1967). Proceedings of the Royal Society of Medicine, 60,

698.
Westlund, K. B., and Kurland, L. T. (1953). American fournal of Hygiene, 57, 397.

Whitty, C. W. M., and Cooke, A. M. (1949). Fournal of Neurology, Neurosurgery, and Psychiatry, i2, 152

\title{
Disodium Cromoglycate in the Prevention of Induced Asthma
}

\author{
H. HERXHEIMER,* M.D., L.R.C.P.S.ED.\&GLASG. ; HELGA BEWERSDORFF, † M.T.A.
}

Summary : In 13 patients with allergic asthma disodium cromoglycate protected fully only two from an allergen-induced asthmatic attack.

Inhalation of disodium cromoglycate did not improve lung function in five patients with long-standing chronic asthma.

Previous clinical trials do not show convincing evidence that this drug improves bronchial asthma in a high percentage of cases, but it seems to help a small minority of patients.

\section{Introduction}

Recently disodium cromoglycate has been recommended for the treatment of bronchial asthma. Opinion about its usefulness in this disease is divided. The main interest in the substance is based on the report that, if given beforehand, it can protect a patient from an asthmatic attack provoked by the inhalation of antigen aerosol. For this reason it has been recommended mainly for allergic (extrinsic) asthma. Most reports about its effect, however, concern its clinical efficiency in both extrinsic and intrinsic asthma, and experimental work on its preventive aotion in induced asthma has so far been limited. In the experiments reported here we have attempted to suppress induced (provoked) asthma in 13 patients.

\section{Material and Methods}

Of the 13 patients investigated, five had grass pollen asthma, two house dust asthma, and six had flour asthma. The diagnosis was proved by the history, by skin testing, and by bronchial testing. The investigations took place during a period in which the asthmatic complaint was latent or at a minimum.

The asthmatic attack was provoked by the method of Herxheimer (1949), while the patient was breathing from a closed-circuit recording spirometer. His basal values for the vital capacity (non-forced, starting from the expiratory level of the tidal air) and peak flow were taken beforehand. Then a measured amount of antigen aerosol was released into the circuit. This dose had previously been determined as being sufficient to induce a mild attack, lowering the vital capacity by 10 to $20 \%$ and the peak flow by 30 to $40 \%$. Breathing was recorded continuously and the vital capacity after 1, 2, 5,

- Director, Asthma Policlinic, Free University, West Berlin. t Assistant, Asthma Policlinic, Free University, West Berlin. and 10 minutes and, if necessary, later. An induced attack became apparent usually within 10 minutes, both subjectively and in the lung function values. When this was the case $2 \%$ isoprenaline sulphate aerosol was released into the circuit and this aborted the attack within a few minutes.

The allergens used were a $5 \%$ grass pollen extract and $5 \%$ mixed pollen extract (Bencard), diluted $1: 10$, house dust extract $5 \%$ (freeze dried, Center Laboratories, Port Washington, N.Y.), and wheat flour. The flour was not given in solution, as were the other allergens, but was inhaled through the nose by means of a powder blower. The amount varied from 10 to $120 \mathrm{mg}$. In the patients we tested we had previously found that such inhalation of flour produced symptoms not only of rhinitis but also of asthma. All patients had been given placebo inhalations on a previous occasion.

Disodium cromoglycate was given as the aerosol of a $5 \%$, later $10 \%$, watery solution in the closed-circuit system. The pure substance, without the admixture of isoprenaline, had been made available to us by the kindness of the makers (Fisons Ltd.). This aerosol had no irritant effect on the subjects. It was inhaled for four to eight minutes-that is, the patient inhaled between 8 and $34 \mathrm{mg}$. and therefore retained (Herxheimer and Stresemann, 1961) between about 6.4 and $28 \mathrm{mg}$. Originally it had been intended to use the Spinhaler for the application of the substance, but on microscopical examination the powdered contents of the cromoglycate capsules to be inhaled by the patients proved to consist mainly of large, partially crystalline clumps with a diameter of $30-50 \mu$ and could therefore not be expected to reach the finer bronchioli.

The inhalation of the provoking allergen was begun 20 to 30 minutes after the cromoglycate inhalation had ended. Apart from preliminary trials each patient took part in three experiments: firstly, an induced attack without cromoglycate; secondly, after three to seven days an induced attack with the same amount of allergen but cromoglycate given beforehand; and thirdly, after a similar interval another induced attack with an equal amount of allergen but without cromoglycate, as a control.

In five other patients with chronic bronchial asthma of the extrinsic or intrinsic type and a reduced but stable lung function cromoglycate aerosol was given in amounts from 8 to $17 \mathrm{mg}$. by the same method. A saline aerosol had been given on a previous occasion and baseline measurements of lung function recorded.

The subjects were informed about the purpose of the investigations and had consented. 
Table of Results

\begin{tabular}{|c|c|c|c|c|c|c|c|}
\hline \multirow{2}{*}{$\begin{array}{l}\text { Sub- } \\
\text { ject }\end{array}$} & \multirow{2}{*}{ Allergen } & \multirow{2}{*}{$\begin{array}{l}\text { Amount } \\
\text { of } \\
\text { Cromo- } \\
\text { glycate } \\
\text { Inhaled }\end{array}$} & \multirow{2}{*}{$\begin{array}{l}\text { Basal } \\
\text { Vit. } \\
\text { Cap. } \\
\text { (ml.) }\end{array}$} & \multirow{2}{*}{$\begin{array}{c}\text { Basal } \\
\text { Peak } \\
\text { Flow } \\
\text { (1./min.) }\end{array}$} & \multicolumn{2}{|c|}{$\begin{array}{c}\text { Percentage } \\
\text { Decrease }\end{array}$} & \multirow{2}{*}{ Result } \\
\hline & & & & & $\begin{array}{l}\text { Vit. } \\
\text { Cap. }\end{array}$ & $\begin{array}{l}\text { Peak } \\
\text { Flow }\end{array}$ & \\
\hline $\mathbf{A}$ & Flour & 10.5 & $\begin{array}{l}4,165 \\
4,330 \\
4,185\end{array}$ & $\begin{array}{l}500 \\
510 \\
485\end{array}$ & $\begin{array}{r}22 \\
5 \\
28\end{array}$ & $\begin{array}{r}14 \\
6 \\
34\end{array}$ & Protected \\
\hline B & Flour & $\overline{10.5}$ & $\begin{array}{l}4,260 \\
4,000 \\
4,180\end{array}$ & $\begin{array}{l}500 \\
475 \\
520\end{array}$ & $\begin{array}{r}24 \\
0 \\
25\end{array}$ & $\begin{array}{r}40 \\
5 \\
51\end{array}$ & Protected \\
\hline C & Flour & $1 \overline{10.5}$ & $\begin{array}{l}3,300 \\
3,100 \\
3,050\end{array}$ & $\begin{array}{l}420 \\
420 \\
400\end{array}$ & $\begin{array}{l}27 \\
11 \\
34\end{array}$ & $\begin{array}{r}26 \\
7 \\
30\end{array}$ & $\begin{array}{l}\text { Partially } \\
\text { protected }\end{array}$ \\
\hline $\mathrm{D}$ & Flour & $\begin{array}{r}\overline{8 \cdot 4} \\
16 \cdot 8 \\
33 \cdot 6 \\
-\end{array}$ & $\begin{array}{l}4,800 \\
4,720 \\
4,700 \\
4,435 \\
4,640\end{array}$ & $\begin{array}{l}580 \\
535 \\
530 \\
530 \\
543\end{array}$ & $\begin{array}{l}37 \\
40 \\
10 \\
33 \\
50\end{array}$ & $\begin{array}{r}41 \\
\mathbf{4 4} \\
8 \\
30 \\
43\end{array}$ & $\begin{array}{l}\text { Partially } \\
\text { protected } \\
\text { by } 16 \cdot 8 \\
\text { mg. but } \\
\text { not by } 8 \cdot 4 \\
\text { and } 33.6 \\
\text { mg. }\end{array}$ \\
\hline $\mathrm{E}$ & Flour & $\overline{10 \cdot 5}$ & $\begin{array}{l}3,550 \\
3,400\end{array}$ & $\begin{array}{l}298 \\
220\end{array}$ & $\begin{array}{l}27 \\
13\end{array}$ & $\begin{array}{l}46 \\
30\end{array}$ & $\begin{array}{l}\text { Possibly } \\
\text { part pro- } \\
\text { tected* }\end{array}$ \\
\hline $\mathrm{F}$ & Flour & $\overline{12 \cdot 6}$ & $\begin{array}{l}5,230 \\
5,200 \\
5,240\end{array}$ & $\begin{array}{l}485 \\
510 \\
520\end{array}$ & $\begin{array}{l}5 \\
3 \\
6\end{array}$ & $\begin{array}{l}20 \\
21 \\
16\end{array}$ & $\begin{array}{l}\text { Not } \\
\text { protected }\end{array}$ \\
\hline G & $\begin{array}{c}\text { Grass } \\
\text { pollen }\end{array}$ & $\overline{8 \cdot 4}$ & $\begin{array}{l}4,900 \\
4,900 \\
\end{array}$ & $\begin{array}{l}630 \\
630 \\
\end{array}$ & $\begin{array}{r}8 \\
13\end{array}$ & $\begin{array}{l}10 \\
12\end{array}$ & $\left\{\begin{array}{l}\text { Not } \\
\text { protected* }\end{array}\right.$ \\
\hline $\mathbf{H}$ & $\begin{array}{c}\text { Grass } \\
\text { pollen }\end{array}$ & $\overline{12 \cdot 6}$ & $\begin{array}{l}2,800 \\
2,500\end{array}$ & $\begin{array}{l}415 \\
400\end{array}$ & $\begin{array}{l}30 \\
42\end{array}$ & $\begin{array}{l}30 \\
55\end{array}$ & \} $\begin{array}{l}\text { Not } \\
\text { protected }\end{array}$ \\
\hline I & $\underset{\text { pollen }}{\text { Mixed }}$ & $\overline{12 \cdot 6}$ & $\begin{array}{l}2,690 \\
2,710 \\
2,575\end{array}$ & $\begin{array}{l}305 \\
315 \\
290\end{array}$ & $\begin{array}{l}40 \\
19 \\
35\end{array}$ & $\begin{array}{l}18 \\
27 \\
36\end{array}$ & $\begin{array}{l}\text { Not } \\
\text { protected }\end{array}$ \\
\hline $\mathrm{J}$ & $\begin{array}{c}\text { Mixed } \\
\text { pollen }\end{array}$ & $1 \overline{10 \cdot 5}$ & $\begin{array}{l}4,220 \\
3,870 \\
3,760\end{array}$ & $\begin{array}{l}530 \\
510 \\
480\end{array}$ & $\begin{array}{l}14 \\
18 \\
20\end{array}$ & $\begin{array}{l}26 \\
14 \\
39\end{array}$ & protected \\
\hline K & $\begin{array}{c}\text { Mixed } \\
\text { pollen }\end{array}$ & $\frac{-}{10.5}$ & $\begin{array}{l}4,790 \\
5,020 \\
4,950\end{array}$ & $\begin{array}{l}270 \\
492 \\
400\end{array}$ & $\begin{array}{l}42 \\
22 \\
27\end{array}$ & $\begin{array}{l}13 \\
49 \\
41 \\
\end{array}$ & $\begin{array}{l}\text { Not } \\
\text { protected }\end{array}$ \\
\hline $\mathbf{L}$ & $\begin{array}{l}\text { House } \\
\text { dust }\end{array}$ & $\overline{10 \cdot 5}$ & $\begin{array}{l}4,990 \\
5,070\end{array}$ & $\begin{array}{l}440 \\
430\end{array}$ & $\begin{array}{l}30 \\
18\end{array}$ & $\begin{array}{l}58 \\
55\end{array}$ & \} $\begin{array}{l}\text { Not } \\
\text { protected }\end{array}$ \\
\hline$M$ & $\begin{array}{l}\text { House } \\
\text { dust }\end{array}$ & $\frac{\overline{10 \cdot 5}}{-}$ & $\begin{array}{l}3,880 \\
4,170 \\
4,310\end{array}$ & $\begin{array}{l}420 \\
498 \\
485\end{array}$ & $\begin{array}{l}35 \\
48 \\
58\end{array}$ & $\begin{array}{l}16 \\
57 \\
49\end{array}$ & $\left\{\begin{array}{l}\text { Not } \\
\text { protec ted }\end{array}\right.$ \\
\hline
\end{tabular}

* Second control studies could not be carried out because these two subjects did not attend for further studies. Their results are included in the table as the control experiment could not have affected the result in Case $\mathrm{E}$, and

\section{Results}

The results are shown in the Table and the Chart. Of the six flour-sensitive patients, two were fully and one was partly protected ; there was little or no protection in the other three. None of the grass pollen and house dust patients was protected. Lung function did not change under the influence of cromoglycate-for example, vital capacity and peak flow after

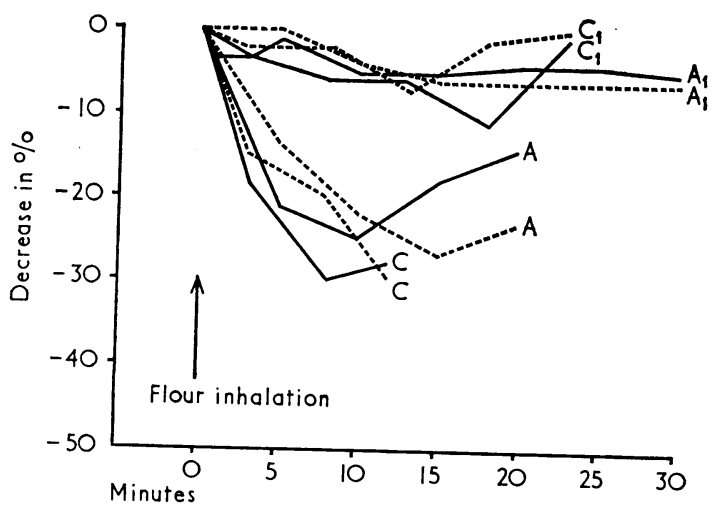

$A_{1}$ and $C_{1}$ describe the experiments on the two subjects fully protected by disodium cromoglycate. $A$ and $C$ are the averages of two control experiments with the same subjects, but without disodium cromoglycate. capacity. ...... Peak expiratory flow (P.E.F.).
. the inhalation of cromoglycate and before provocation were about the same as the basal values. All flour-sensitive patients showed symptoms of rhinitis, even when their lung funotion was protected by cromoglycate. In the five chronic asthmatic patients who were given cromoglycate aerosol lung function changed only trivially.

\section{Discussion}

Altounyan (1965) reported that three allergen-sensitive patients were protected by cromoglycate for two hours and longer. Pepys et al. (1968) induced asthma in one patient with grass pollen asthma, in four patients with mite asthma, and in five with aspergillosis or bird-fancier's disease. Their summary states that all were fully protected by the inhalation of $20 \mathrm{mg}$. of cromoglycate powder from a Spinhaler, but it is pointed out in the text that one of the mite asthma patients was only partially protected. Our experiments present a less clear-cut result. Protection was present in only 2 out of 13 cases, and partial protection in another, while there was a possibility but no definite evidence of protection in two others. Nevertheless, it must be regarded as certain that the substance may protect from induced asthma, though it is so far unknown for what reasons and by what mechanism. Nor can we say why one individual case is protected and another is not, or why protection in our series occurred only in flour-sensitive patients.

We cannot say why our results differ so much from those of Pepys et al. (1968). The reasons may well be sought in the different methods. The efficiency of the cromoglycate powder, if the powder used by these authors was of the same coarse kind as in our capsules, must be seriously questioned; the measurements of lung function used by these authors-the F.E.V. and, in particular, the forced vital capacity-are not advisable in asthmatics (though they are now the fashion) because these measurements in themselves impair lung function, and not always to the same degree (Herxheimer, 1963). Also the allergen was not given in a closed circuit, so that the amount of allergen retained is difficult to estimate. These considerable differences in method make it difficult to compare our series and that of Pepys et al.

Another difference between our results and those of Pepys et al. is that the basal lung function values were not increased by cromoglycate. Here again the method of measurement may be of importance.

It could be argued that the amount of cromoglycate in the present experiments has been smaller than that given through the Spinhaler. We do not believe that the coarse particles in the Spinhaler can have more than a fraction of the effect of a fine aerosol such as we used. Even the minimum we gave $(6 \mathrm{mg}$.) should have had a greater effect than $20 \mathrm{mg}$. of powder from the Spinhaler. This is supported by Altounyan's (1965) finding that even $1 \mathrm{mg}$. of cromoglycate given as an aerosol in two of his original experiments had a definite protective effect. Also, the makers have confirmed that the watery solution of cromoglycate given as an aerosol should have a similar protective effect as the powder.

The negative result in our lung function tests in five chronic asthmatics after cromoglycate must be considered in relation to the published results of others. Howell and Altounyan (1967) treated 10 severe asthmatics over six weeks with $80 \mathrm{mg}$. of Spinhaler powder daily and found clinical improvement in all of them, but lung function improvement in only four. Kennedy (1967) treated 57 labile allergic asthmatics and found pronounced improvement in 11 and definite improvement in 17. As labile asthma tends to change spontaneously, this source of error seems considerable.

Smith and Devey (1968) gave $80 \mathrm{mg}$. of cromoglycate with (as in the earlier series) isoprenaline to 44 children with longstanding perennial asthma, of whom 21 were on corticosteroid maintenance doses of between 2.5 and $15 \mathrm{mg}$. of prednisone 
daily. The asthma of more than half of these patients seems either to have been very mild or very well controlled by prednisone, for 24 children never needed their inhaler when on placebo and 28 when on cromoglycate, this difference being negligible. Of the 17 children on steroids, three were able to reduce them on cromoglycate from 5 to $2.5 \mathrm{mg}$. and one was able to reduce them from 15 to $10 \mathrm{mg}$., again a negligible difference. If asthmatic patients who are almost well are used in such a trial much difference in their state cannot be expected, even if they were to improve. Moran et al. (1968) treated 21 allergic patients, of whom 11 improved. But most of these patients had little or no sputum. This suggests that their asthma was very mild and intermittent. We know hardly any patients with chronic asthma without cough and sputum.

Most of these investigations seem to have been done with the coarse cromoglycate powder which will hardly have reached regions lower than the largest bronchi. Moreover, they concern patients without a stable chronic asthma who are not suitable for trials of this kind. It is not surprising that the authors report improvement of about $50 \%$, the same percentage which has been reported with many other so-called asthma remedies which have long been forgotten. In these circumstances we reluctantly agree with the unenthusiastic attitude of Kidner et al. (1968), who found an improvement in $38 \%$ of their 28 patients but say that the difference between cromoglycate and placebo was seldom striking. We can also agree with Grant $(1968,1969)$, who did not see a statistically significant degree of improvement.
Such an improvement can hardly be expected if our protection experiments are correct. On the other hand, we are convinced that cromoglycate can protect or improve individual patients, perhaps one in ten or one in five. This small chance of improvement is reminiscent of the transitory role of khellin, from which disodium cromoglycate seems to be derived, played some years ago in the treatment of asthma. At that time many observers thought that khellin was effective, but only in a few individual cases, not enough to make it a generally useful treatment. Nevertheless, we agree with previous observers that cromoglycate may prove to be an interesting and valuable research tool.

\section{REFERENCES}

Altounyan, R. E. C. (1965). Summary of information on FPL 670. Fisons Ltd.

Grant, I. W. B. (1968). Lancet, 2, 282.

Grant, I. W. B. (1969). British Medical fournal, 1, 842.

Herxheimer, H. (1949). Fournal of Physiology (London), 109, 4P.

Herxheimer, H. (1963). Acta Allergologica (Kфbenhavn), 18, 1.

Herxheimer, H., and Stresemann, E. (1961). Naunyn-Schmiedeberg's Archiv für experimentelle Pathologie und Pharmakologie, 241, 225. Howell, J. B. L., and Altounyan, R. E. C. (1967). Lancet, 2, 539.

Kennedy, M. C. S. (1967). Lancet, 2, 838.

Kidner, P. H., Meisner, P., Pride, N. B., and Pearson, R. S. B. (1968). Lancet, 2, 655.

Moran, F., Bankier, J. D. H., and Boyd, G. (1968). Lancet, 2, 137. Pepys, J., Hargreave, F. E., Chan, M., and McCarthy, D. S. (1968).
Lancet, 2, 134 .

Smith, J. M., and Devey, G. F. (1968). British Medical fournal, 2, 340.

\title{
Arterial Pressures in Rural and Urban Populations in Nigeria
}

\author{
O. O. AKINKUGBE,* M.D., D.PHIL., F.R.C.P.ED.; O. A. OJO, $\dagger$ M.D., M.A.O., M.R.C.O.G.
}

\begin{abstract}
Summary : Surveys of arterial pressure carried out in $N$ rural and urban communities in Western Nigeria showed a steady rise in systolic values with age, this trend being less marked with diastolic pressures. Blood pressure levels were similar in women from rural and urban areas, but seemed much higher in urban than in rural men. The incidence of proteinuria was lowest in the female urban group. In general, the incidence of proteinuria or glycosuria was low and did not appear to be related to the blood pressure.
\end{abstract}

\section{Introduction}

There is a good deal of evidence to show that the arterial pressure in Negro populations in the United States and in the West Indies is higher than in white populations (Adams, 1932; Gover, 1948 ; Johnson and Remington, 1961). As the ancestors of Negroes in these areas came from the west coast of Africa it seemed worth while to examine data from indigenous populations of West Africa for comparison, so that the influence on the blood pressure of different environments and socio-economic and other factors in Negroes might be more clearly understood.

* Profess $\cdot r$ of Medicine.

† Professor of Obstetrics and Gynaecology.

University of Ibadan, Nigeria.

\section{Methods}

Two populations in Western Nigeria were defined-one rural and the other urban-and the study was carried out in two stages.

Rural Study.-Eruwa, a village conglomeration with a population of 22,000 in the Ibarapa District of Western Nigeria, lies in rolling savannah country just outside the belt of tropical rain forest. The vast majority of its inhabitants are illiterate, the sources of livelihood being farming. Two factors account for the selection of this village for study: firstly, the inhabitants are already accustomed to medical surveys, and, secondly, the population is stable and ethnically homogeneous, being composed almost entirely of the Yoruba tribe. The village was divided into four wards and each ward into an enumeration area comprising 25 to 30 houses, the number of people in an area ranging from 200 to 900 . Each enumeration area was grouped into units according to size, a unit consisting of 200 inhabitants. Thus there were 103 units, of which 20 were randomly selected. Altogether 3,602 subjects aged 5 to over 70 years were examined (1,696 males and 1,906 females), giving a response rate of about $90 \%$.

Urban Study.-To a large extent Ibadan is a city-village, with a million inhabitants (Lloyd, 1967). Its core is peopled by farmers, small traders, and artisans living in large compounds organized on principles of common descent. Those 